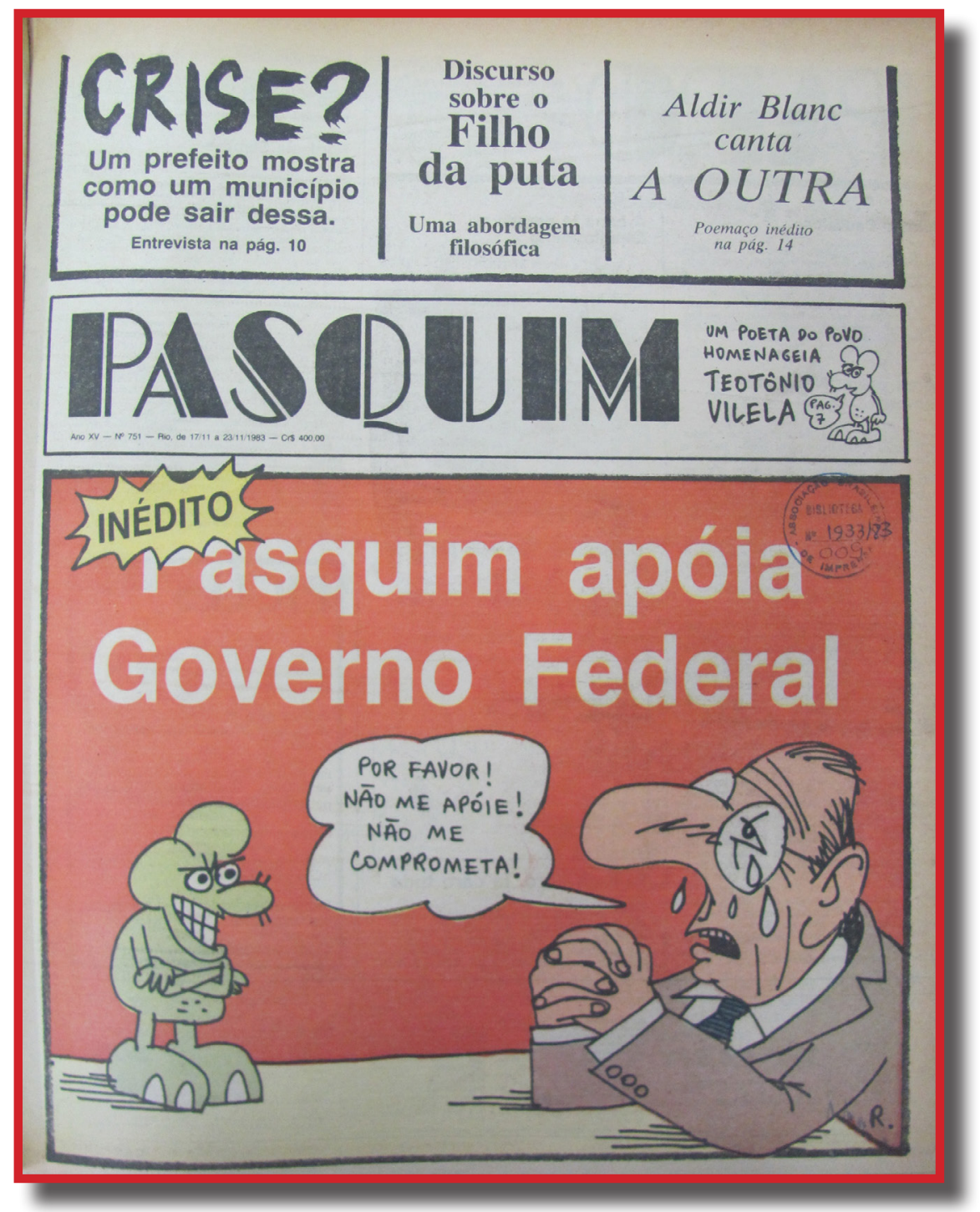

Figura - Jaguar

Fonte: O Pasquim n 751, noviembre de 1983 


\title{
La Caricatura Política en O Pasquim bajo la Dictadura Militar (1978-1980)
}

\author{
Mara Burkart
}

Magíster en Sociología de la Cultura y Análisis Cultural por el IDAES, Universidad Nacional de San Martín; y Doctora en Ciencias Sociales por la Universidad de Buenos Aires. Su proyecto actual de investigación consiste en analizar las relaciones entre cultura y política de modo comparativo en Brasil y Argentina a partir del análisis de las revistas de humor gráfico de ambos países bajo las respectivas dictaduras militares. maraburkart@yahoo.com.

\begin{abstract}
RESUMO
O Pasquim surgió al poco tiempo de instaurado el Ato Institucional $n^{\circ} 5$ que inauguró el período más represivo de la dictadura militar brasileña. Fue una publicación de humor gráfico que interpeló a una clase media urbana, culta, bohemia y desprejuiciada. En él, la risa cómica irrumpió como un espacio crítico y desafiante de los proyectos de orden que los militares quisieron imponer. En O Pasquim, la imagen tuvo un papel central pero la caricatura política tuvo una incorporación tardía, a mediados de 1978, cuando buena parte de la sociedad brasilera ansiaba la distensión política y del fin del $\mathrm{Al}^{\circ}$ 5. La propuesta de trabajo es analizar las caricaturas de Geisel y Figueiredo publicadas en O Pasquim entre 1978 y 1980 para dar cuenta de sus características, potencialidad y eficacia en las luchas simbólicas que se desarrollaron en la mencionada coyuntura, y de su relación con la censura..
\end{abstract}

Palabras clave: Dictadura militar brasilera. Caricatura política. O Pasquim.

\begin{abstract}
O Pasquim was published in 1969, soon after the Ato Institucional $n^{\circ} 5$ was drawn, a regulation that opened the most repressive period of the Brazilian military dictatorship. O Pasquim was a comic magazine addressed to an educated, bohemian and unprejudiced urban middle class. Laughter was a defiant answer to the order the militars wanted to seek. The image in the magazine played a central role, however the political caricature was incorporated a bit later. It occurred in the midst of 1978, when part of the Brazilian society was looking forward to the political distension and the end of Al-5. The aim of this article is to analyze Geisel's and Figueiredo's caricatures published in O Pasquim between 1978 and 1980 to determine their specific characteristics, potentiality and efficiency in the symbolic struggle that took place under the mentioned circumstances, and their relationship with censorship.

Keywords: Brazilian military dictatorship. Political cartoons. O Pasquim.
\end{abstract}


En diciembre de 1968, las Fuerzas Armadas, instaladas en el poder desde 1964, reforzaron su poder autoritario y represivo al imponer el Ato Institucional $\mathrm{n}^{\circ}$ 5. A diferencia de los Atos Institucionais anteriores, éste no estipulaba plazo para su vigencia con lo cual el control y la suspensión de las garantías constitucionales se tornaban permanentes. El Al-5 concedió amplios poderes al Poder Ejecutivo y "abriu caminho para a descontrolada utilização do Aparato Repressivo do Estado de Segurança Nacional" (ALVES, 1984, p. 135). Su vigencia implicó la disolución del Congreso, restricciones al poder judicial y la suspensión del habeas corpus para crímenes políticos. Se trataba de la reacción oficial principalmente a la rebeldía de ARENA para actuar como partido de gobierno y votar en contra de varias iniciativas de Poder Ejecutivo (SKIDMORE, 1988); pero también era la respuesta a las movilizaciones estudiantiles y de trabajadores que se había comenzado a suceder. De este modo, la dictadura, por un lado, iniciaba un nuevo ciclo de represión, el cual se caracterizó por el "indiscriminado emprego da violência contra todas as classes" (ALVES, 1984, p. 141); por otro, encontraba la vía para institucionalizar el control de las instituciones de la sociedad civil con el establecimiento de la censura previa directa sobre los medios de comunicación, el control de la participación política y de las instituciones educativas. Y finalmente, lograba el encuadramiento legal para el nuevo modelo de desarrollo económico que en aquel entonces se conoció como "milagre econômico".

Si bien el Al-5 instauró un período de silencio, miedo, confusión y desánimo también generó las condiciones de posibilidad para el surgimiento de diversas formas de resistencia. En este contexto, la opción por la lucha armada adquirió un fuerte impulso, dando lugar al surgimiento de organizaciones guerrilleras urbanas tanto como rurales. Pero también hubo formas no violentas de oposición al régimen. En este trabajo nos interesa el caso de O Pasquim, exponente de la prensa alternativa. Surgido en Río de Janeiro a los pocos meses de instaurado el Al-5, O Pasquim fue una publicación de humor gráfico que se caracterizó por salir a la conquista del público masivo, jugar bajo las reglas del mercado y del campo editorial y por ser independiente, es decir, por no ser editado por una gran casa editorial sino por dibujantes devenidos editores. Inscripto abiertamente en la cultura de izquierdas, se constituyó en un espacio desafiante de la censura y de los proyectos de orden que los militares quisieron imponer. Con él, la risa irrumpió como un espacio crítico que aportó aire fresco en un clima político social marcado por la clausura del espacio público, la ausencia de libertades civiles y políticas, la violencia política y el terrorismo de Estado. Por todo esto y por desafiar los límites de lo permitido y autorizado por las autoridades de facto, fue objeto de censura y persecución, y su equipo sufrió amenazas y hasta fue encarcelado.

Inicialmente, O Pasquim interpeló a la bohemia del barrio carioca de Ipanema pero al poco tiempo se abrió hacia una clase media culta, urbana, bohemia, comprometida, (aparentemente) desprejuiciada y ansiosa de libertad. La revista expresó la revolución cultural sesentista (Hobsbawm, 1998) en clave brasilera. Así, el fomento que hizo de la modernización cultural tuvo un giro más audaz e irreverente que el conservadurismo oficial y oficialista que también promovía cambios en el ámbito cultural pero en sentido de una "modernización conservadora" (MOORE, 1991). El contexto represivo y el imperio de la censura contribuyeron a que la 
revista en sus primeros años se dedique más a la crítica de las costumbres y de aspectos de la cultura. Sin embargo, las referencias a la política internacional y nacional no estuvieron del todo ausentes. A medida que la revista fue conquistando lectores y obteniendo el reconocimiento de sus pares, y la censura se aflojó; el abordaje de los temas políticos se hizo más recurrente.

O Pasquim se editó semanalmente entre 1969 y 1991. La propuesta de este trabajo es analizar una coyuntura específica de la larga y prolífica historia de este periódico, aquella que se caracterizó por la incorporación de la caricatura política al arsenal de recursos utilizado por sus editores. De modo más específico, nos proponemos analizar las representaciones visuales cómicas de Ernesto Geisel y João Figueiredo publicadas en $O$ Pasquim entre 1978 y 1980, esto es, desde la irrupción de este tipo de imágenes y la designación de Figueiredo como sucesor de Geisel hasta el primer año del gobierno de aquel. El objetivo es dar cuenta de la potencialidad y eficacia de estas imágenes cómicas a través de su participación en las luchas simbólicas que se desarrollaron en la mencionada coyuntura y su relación con la censura. O Pasquim, que aún hoy en día es recordada como ejemplo de la prensa alternativa y de la "resistencia cultural", ha sido objeto de numerosas investigaciones académicas. Sin embargo, por lo general, ha sido soslayado el análisis de sus imágenes y el énfasis se ha colocado en sus primeros años de existencia. Como ejemplo, podemos mencionar el trabajo pionero de José Luiz Braga (1991) y el más reciente de Paulo Petrini (2012) que analiza las imágenes publicadas en $O$ Pasquim en los primeros años setenta, sin avanzar en los años posteriores cuando fue más recurrente el uso de la caricatura política ${ }^{1}$. Por mi parte, he realizado una primera aproximación a este tema en un artículo que compara la caricatura política en O Pasquim y en la revista argentina $\mathrm{HUM}^{\circledR}$ (BURKART, 2012). El propósito de este artículo es profundizar en el análisis de las imágenes cómicas de O Pasquim.

\section{Las imágenes cómicas de "O Pasquim"}

En O Pasquim, la imagen tuvo un papel central. Si bien la fotografía, el fotomontaje y el dibujo humorístico fueron más importantes que la caricatura política, ésta no estuvo ausente. Su incorporación fue tardía, se produjo cuando, hacia mediados de 1978 , buena parte de la sociedad brasilera estaba a la espera de la distensión política y del fin del Al-5, instaurado diez años antes. Como señala Braga (1991, p. 91), fue recién "com Figueiredo, desde antes da posse, que vai haver uma retomada da caricatura política". Esta novedad de O Pasquim coincidió con el despliegue que tuvo la caricatura de Chico Caruso en el Jornal do Brasil². Según Ziraldo, Chico "reavivou a caricatura brasileira" aunque él mismo tuvo que "reaprender a fazer caricatura pessoal" (BRAGA, 1991, p. 91). En 1978 hacía tres años que se había levantado la censura previa sobre O Pasquim. Es posible que el temor a verse nuevamente sometidos a su imperio haya postergado la incorporación de este tipo de imágenes. Esta apreciación se basa en el hecho de que la censura no

1 También se pueden mencionar los trabajos de Buzalaf (2009), Dagneze (2010), Ferreira (2009), Figueiredo (2013), Kusinski (2003), Oliveira (2007), Queiroz (2008, 2004); Sohiet $(2007,2005)$, entre otros. 2 También a principios de 1978, el semanario Movimento (1975-1981) publicó en su portada dibujos de Figueiredo realizados por Jaume Leão que con el tiempo devienen más caricaturescos. 
había desaparecido por completo, la revista Veja y los periódicos alternativos Opinião y Movimento seguían con censura previa e incluso, O Pasquim no dejó de ser censurado ni de ser investigado por los servicios de inteligencia del régimen. A este temor, se sumaba la cuestión planteada por Ziraldo, los humoristas del semanario no estaban habituados a hacer este tipo de imágenes. $Y$ la revista, con casi diez años de trayectoria, había construido un contrato de lectura que prescindía de ella. Desde sus inicios, $O$ Pasquim publicó imágenes cómicas pero éstas no eran retratos "cargados" (caricare), injuriosos, de personalidades reconocidas sino más bien de individuos genéricos (políticos, policías o militares, hombres y mujeres, etc.). También solía publicar caricaturas benignas o laudatorias, que cumplían el papel de ilustrar notas escritas.

En todo caso, una vez que aparecieron, la galería de personajes del mundo de la política se fue ampliando. Las caricaturas políticas de $O$ Pasquim no fueron realizadas por un único humorista sino por varios, algunas de ellas se publicaron en la portada, otras fueron parte de cartoons o tiras cómicas publicadas en el interior de la revista. En ellas el color no fue un aspecto central como tampoco lo fue el retrato grotesco, aunque éste, como se verá, no estuvo del todo ausente. La mayor parte de los dibujantes privilegiaron la esquematización y, en muchos casos, la representación de situaciones jocosas en las cuales el texto, más que la imagen, era el que contenía la comicidad. En otras palabras, la caricatura estuvo generalmente al servicio del charge, del abordaje cómico de una situación o hecho político, donde la persona caricaturizada es un elemento más.

La caricatura es la manera en que se expresa visualmente la sátira, demostrando ser un instrumento eficaz para el ataque político. Peter Berger define a la sátira como "un ataque que forma parte de un programa del que la esgrime. Dicho de otro modo, en la sátira, la intención agresiva se convierte en motivo central de la explicación cómica. Todos los elementos de lo cómico se funden entonces, en cierto modo, para constituir un arma" (BERGER, 1999, p. 255). El hecho de que estén involucrados todos los elementos de lo cómico, alude a la advertencia que José E. Burucúa hace cuando señala que las formas de la risa no se presentan de modo puro, sus fronteras son porosas y se contaminan unas a las otras:

sobre todo la satírica, que parecería tener el carácter de un centro de gravedad universal de lo cómico. No habría risa, pues, que no tenga una carga de crítica de la sociedad y de las costumbres. Pero al mismo tiempo, la recíproca es verdadera: toda risa satírica, por mordaz y destructora que se quiera, se impregna del sentido reparador y cicatrizante que posee la carnavalesca y deja que asome, aunque no sea sino un atisbo, la esperanza de vislumbrar lo sublime, lo no condicionado por el dolor y la muerte (BURUCÚA, 2007, p. 53).

Es en este terreno resbaladizo de lo cómico donde se mueve la risa promovida por O Pasquim bajo la dictadura militar. La risa satírica y crítica es aquella "que ataca sin violencias físicas ni injurias a los poderosos en el gobierno, en la vida intelectual y en la religión, a los políticos, los eruditos, los sacerdotes; ella lo hace sin demasiadas esperanzas, pues a menudo le basta la alegría pasajera que produce en los cuerpos y las almas" (BURUCÚA, 2007, p. 51). La caricatura exagera y deforma, rebaja y desenmascara, "Uno puede volver cómica a una persona para hacerla despreciable, para restarle títulos de dignidad y autoridad" (FREUD, 1986, p. 180).

Todo ello produce placer y un sentimiento 
de superioridad tanto en el productor como en el consumidor de estas imágenes. La eficacia de la caricatura reside en la capacidad de involucramiento que el dibujante logra del espectador. Para Freud (1986), este involucramiento es en carácter de cómplice en contra de un enemigo al que se torna cómico al exponerlo rebajándolo, volviéndolo inferior y despreciable. Laura Malosetti Costa da cuenta de aquella complicidad en términos de cohesión:

Aún las caricaturas más feroces no tienen como objetivo principal atacar o provocar la violencia sino más bien cohesionar y tranquilizar a quienes ya están convencidos, estableciendo conexiones entre lo familiar y lo no familiar. El caricaturista juega con las metáforas, produce metáforas visuales a partir de imágenes reconocidas y reconocibles para opinar, para provocar la risa a partir de un pacto con sus lectores/espectadores (MALOSETTI, 2002, p. 3).

Peter Berger discute con esta idea, "no es necesario que el público esté de acuerdo de antemano con el satírico. La sátira también puede ser educativa: los esfuerzos del satírico pueden tener como resultado que el público acabe comprendiendo la indeseabilidad de lo atacado" (1999, p. 256).

La caricatura política puede expresar un sentido opositor y hasta moral de una determinada situación o actor político. Por este motivo, el caricaturista puede así ser considerado un sujeto peligroso ya que:

nos ha enseñado a verlo de manera novedosa, a verlo como una criatura ridícula. Esto es la verdad de fondo y el objetivo oculto detrás del arte del caricaturista. [...] Con un par de líneas puede desenmascarar al héroe público, reducir sus pretensiones y hacer un stock gracioso de él. Contra este hechizo hasta el más poderoso queda impotente (GOMBRICH, 1979, p. 6).

Pero también, el caricaturista puede ser un cronista de la época ya que la caricatura política está ligada al tiempo y al lugar en que fue realizada, lo que hace necesario explicarla, describirla y contextualizarla para que adquiera sentido y resalte lo que no surge a la vista. En palabras de Eduardo Romano, "la caricatura es arte de circunstancias, la caricatura pierde vigencia rápidamente o se convierte en un auxiliar de la información histórica en tanto crónica informal y expresiva de una época, un lugar, un proceso" (1990, p. 89-90). La fugacidad de la caricatura puede conllevar el peligro de reducirlas a un simple reflejo del contexto en que fueron realizadas.

La caricatura política también posee un carácter trascendente en tanto "trasmite un sentimiento de liberación que rebasa el momento histórico concreto" (BERGER, 1999, p. 257). Si bien, la sátira asistió a un proceso de secularización no deja de estar asociada a la magia, para sus víctimas "sigue siendo una maldición y sus efectos sobre los individuos contra los cuales se dirige pueden ser en verdad muy destructivos" (BERGER, 1999 , p. 259). Como ya señalaba Gombrich (1979, p. 297): "el secreto de una buena caricatura [es] ofrecer una fisonomía, una interpretación que nunca podremos olvidar y que la víctima parecerá acarrear siempre, como un embrujado". En 1855, Charles Baudelaire distinguió dos dimensiones de valor de la caricatura que Laura Malosetti Costa (2002) denomina "valor transitorio", por lo cual lo cómico fugitivo está centrado en la vigencia del hecho que representa; $y$ "valor permanente", la caricatura artística entendida como aquella capaz de contener un elemento misterioso, duradero, eterno. Dar cuenta de ambas dimensiones, que remiten al carácter fugaz y trascendente, permite evitar que la imagen cómica quede reducida a un simple "auxiliar", como señala Romano, y pueda considerársela protagonista de la historia. 


\section{Militares caricatos}

\section{Geisel: el encubridor y el pastor}

La aparición de la caricatura en $O$ Pasquim coincidió con la designación de João Figueiredo como sucesor de Ernesto Geisel en la presidencia de la Nación. En un contexto de revitalización de la oposición al régimen por parte de importantes sectores de la sociedad civil, estas caricaturas se sumaron a dicho esfuerzo desde el campo de las luchas simbólicas. O Pasquim, que ya venía expresando en sus textos, entrevistas, historietas y cartoons su oposición y crítica a la dictadura militar redoblaba la apuesta al sumar el dibujo satírico de las autoridades militares a su arsenal de armas simbólicas.

La crítica al presidente de facto Geisel se expresó en torno a tres cuestiones: la corrupción que se hizo pública al final de su mandato, la persistencia de prácticas autoritarias y la designación de su sucesor. A mediados de 1978, el diario alemán Der Spiegel denunció la desaparición de millones de dólares destinados a un acuerdo nuclear entre Alemania y Brasil. O Pasquim, con sarcasmo y amargura, lo consideró "mais um milagre brasileiro" (OP n ${ }^{\circ} 482$, sep. 1978) y, en un gesto de gran audacia, trató al tema en su tapa. En un fotomontaje, diversos aliados e integrantes del gobierno ${ }^{3}$ aparecían bañados en un "Mar de Lama" (OP n 486, oct. 1978). Si bien la imagen de tapa no incluía a Geisel entre los acusados de corrupción, el presidente no quedó indemne. En el interior de la revista, la denuncia se explayaba en una extensa nota y varios charges denunciaban

3 Los denunciados eran Mário H. Simonsen, ministro de Hacienda, el general Golbery de Couto e Silva, Jefe de Gabinete, Shigaeki Ueki, ministro de Minas y Energía; Delfim Netto, ex ministro de Hacienda; ePaulo Maluf, ex secretario de Transporte y futuro gobernador de São Paulo. a Geisel de encubridor. Hélio lo comparó con una gallina gigante que cobijaba en su nido a sus "pollos" $y$, si bien la imagen ya hablaba por si sola, a un costado un hombre se quejaba: "É só a gente denunciar uma falcatrua, que eles correm logo para a toca!" $\left(O P n^{\circ} 484\right.$, oct. 1978). Sin embargo, fueron la tira cómica de Guidacci, "Achado não é roubado" (OP n 486, oct. 1978. Figura 1), y la nota "Mar de lama" las que disgustaron a las autoridades militares. La tira cómica irritó por la representación que se hacía de Geisel, de su secretario, Heitor de Aquino, de Delfim Netto y de Golbery. Si estos tres últimos, eran corruptos desde la primera hora; Geisel pasaba de la sorpresa y el silencio a la complicidad con aquellos.

Por estas denuncias, O Pasquim fue presionado y amenazado de ser encuadrado en la Ley de Seguridad Nacional ${ }^{4}$. El diario O Estado de São Paulo informó que Jaguar, Sérgio Augusto y Guidacci, todos colaboradores de O Pasquim, "serão processados e julgados pela $2^{\circ}$ Auditoria da Aeronáutica do Rio de Janeiro, sob a acusação de crime contra a segurança nacional" y la noticia fue levantada por el Serviço Nacional de Informações de São Paulo (ESP, 14/03/1979 en Informe n० 191/116/ASP/79; SIN, 20/03/1979). Ni siquiera el hecho de que Guidacci tuviera vínculos familiares con uno de los ministros que debía votar por su procesamiento, impidió la acusación. O Pasquim no ocultó

4 Esta ley en realidad es el decreto-ley n ${ }^{\circ} 898$ del 29 de septiembre de 1969. Ella definía los crímenes contra la Seguridad Nacional y el orden público y social, así como los procesos legales de juzgamiento y las penas a ser impuestas a cada crimen. Esta ley reemplazaba la anterior y primera ley de Seguridad Nacional, decreto ley ${ }^{\circ} 314$ del 13 de marzo de 1967; y ampliaba considerablemente la fuerza represiva de los controles anteriormente establecidos (ALVES, 1984). 
su temor $y$, apelando a un dicho popular brasilero, anunció: "Quem tem jornal tem medo" (OP n 488, oct. 1978).
(OP $\mathrm{n}^{\circ}$ 490, nov. 1978: 3) y enumeraban veinte noticias que perjudicaban al gobierno y que en aquel entonces eran de público conocimiento, desde la referencia los hechos

Figura 1- Guidacci

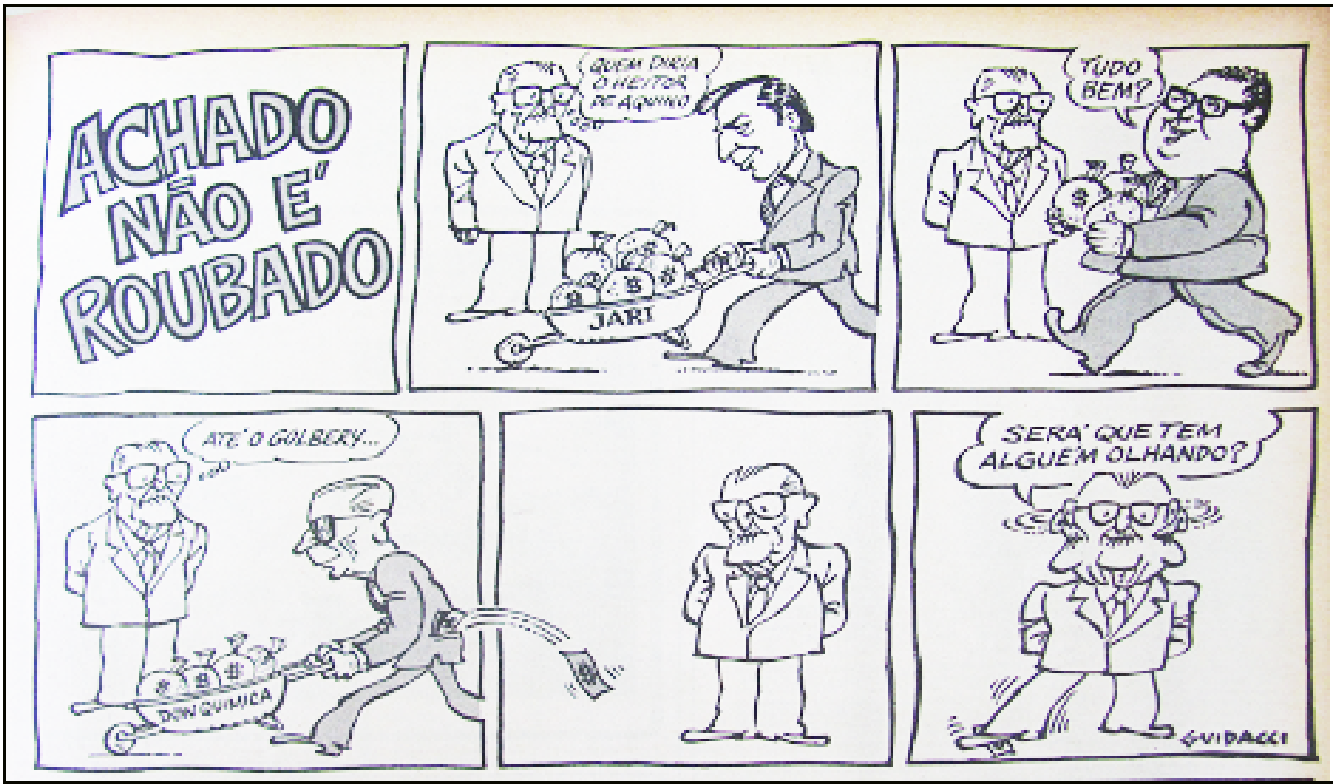

Fonte: O Pasquim n 486, octubre de 1978

En medio de la dialéctica entre miedo y audacia, como señala José Luiz Braga (1991), O Pasquim reforzó su identidad como "um jornal de humor" (OP n 490, nov. 1978). Esta evocación a la risa y al entretenimiento y no a una postura política como estrategia de defensa que reforzaba el lugar de la revista en el campo cultural más que en el político, no obstante, se acompañaba con una retractación. A modo de editorial y con ironía, decían estar equivocados y dejaban entrever que el gobierno había encontrado en este caso la excusa para acallarlos. Se justificaban argumentando que no ofrecían novedad alguna, el tema de la corrupción ya circulaba por otros medios. Irónicamente decían: "São inteiramente mentirosas, inverídicas, provocadoras e carentes de qualquer fundamento as seguintes notícias veiculadas por toda a imprensa brasileira" de corrupción que habían denunciado en "Mar de Lama" hasta el hecho que había 47 presos políticos desaparecidos.

Junto a este editorial, una historieta realizada por Ziraldo declaraba a modo de manifiesto: "Nós, os humoristas, só nos importamos com a corrupção na medida em que ela é ótima para gente fazer piada" y reconocían en ella "apenas uma espinhazinha [...] no corpo doente da nação". Este aparente intento de restarle relevancia a la corrupción no era más que un modo para evitar el procesamiento judicial y para avanzar sobre otras denuncias que en efecto era más profundas, como la injusticia social, la desigualdad en la distribución de la renta nacional, la entrega del suelo y del subsuelo nacional, la mentira generalizada, el desamor por el país, la hipocresía de las medidas a medias que en esencia no transforman nada y la lista continuaba. Sobre estas cuestiones 
podrían hacer muchos chistes pero, decía, "não achamos graça nenhuma!" (OP n ${ }^{\circ} 490$, nov. 1978, p. 27). O Pasquim establecía sus límites $y$, al mismo tiempo, se definía como espacio crítico en el cual la risa era el recurso privilegiado. De este modo buscó impedir el encuadramiento de sus colaboradores y editores bajo la Ley de Seguridad Nacional e incluso contraatacar, al exponer los asuntos pendientes que la dictadura tenía con la ciudadanía.

O Pasquim sobrevivió y no se amedrentó. En la explícita decisión de privilegiar el uso de los recursos de lo cómico para desprestigiar al enemigo $y$, como contrapartida necesaria, enaltecer la propia imagen; sumó denuncias como fue el caso de las escuchas telefónicas ilegales que el gobierno hacía a través de sus organismos de seguridad. Esta vez, la acusación fue directamente a Geisel, se trataba de un "Geiselgate", esto es, "o Watergate dos pobres" (OP n ${ }^{\circ} 485$, oct. 1978). O Pasquim nuevamente cuestionaba la supuesta ignorancia e inocencia de Geisel con respecto a estos hechos. El reciente estreno de la película de Alan Pakula, "Todos los hombres del presidente", donde actuaban Dustin Hoffman y Robert Redford, seguramente inspiró la comparación entre el escándalo de Watergate que había sacudido a Estados Unidos y que había implicado la renuncia del presidente Nixon. Geisel no siguió los pasos de su par norteamericano, ese era más el deseo de los humoristas que una posibilidad concreta. O Pasquim aludió a la ausencia de privacidad producto de la censura telefónica y denunció la incongruencia de esta práctica privativa de los derechos civiles con el discurso oficial que anunciaba la distensión de la censura y la apertura democrática. El control omnipresente del Estado autoritario fue representado por Henfil, en una de sus tiras cómicas el presidente reconocía: "O
Geisel fala e o Geisel escuta" (OP n 485 , oct. 1978). Pero así como Geisel "escuchaba" también era "escuchado", quien lo espiaba, según el mismo Henfil, era Figueiredo, a cargo del SNI y quien ya se sabía que sería su sucesor. Pero, lo que Figueiredo escuchaba, y este era el chiste, era a Geisel reírse de él. Los tentáculos del poder autoritario llegaban hasta las cúpulas militares mismas, a modo de consuelo parecería que nadie estaba libre del mismo.

La designación del sucesor presidencial fue motivo de gran cantidad de chistes. La denuncia del carácter autoritario y antidemocrático de ese tipo de "elecciones" fue recurrente ${ }^{5}$. El cuestionamiento a la legitimidad de las autoridades gubernamentales nombradas en dictadura se articulaba con el desvelamiento de la interna militar, la cual muchas veces cobraba estado público a pesar de los propios militares $^{6}$ (Figura 2). En estos casos, se alternan caricaturas genéricas de militares y civiles con caricaturas personales, es decir, de personas concretas, reconocidas públicamente. Por lo general, los dibujos y los chistes más audaces representaban al primer tipo de caricaturas;

5 En un charge de Hélio, un periodista le pregunta a Geisel: "E quanto à eleição do geral Figueiredo?" y el presidente responde: "A escolha foi legítima! Porque fui eu quem o escolheu" (OP n ${ }^{\circ} 487$, oct.-nov. 1978). 6 Hubo varias las referencias cómicas a los generales Sylvio Frota y Hugo Abreu, los cuales motivaron las divisiones al interior de las Fuerzas Armadas brasileñas. La desmentida sobre tales fraccionamientos quedó representada en un cartoon realizado por Marco, en el cual a su vez filtrar otro tipo de crítica: un militar en una conferencia de prensa responde enfáticamente: "Os militares não estão divididos"; y a continuación, un obrero le responde a un periodista: "a renda também não" $\left(O P \mathrm{n}^{\circ} 479\right.$, sep. 1978). La comparación cuestionaba con audacia los discursos oficiales que resaltaban la cohesión militar. 
cuando se trataba de personas conocidas, la agresividad visual decrecía.

La galería de retratos de Geisel no es particularmente amplia. En ellos, sobresale, en su dimensión transparente, la deformación física. Los rasgos físicos resaltados por los diversos humoristas fueron similares. La vejez del dictador fue constantemente exagerada: arrugas en su cara y cuello junto a su boca hundida fueron comunes. Geisel aparecía como un viejito desdentado, peinado a la gomina, siempre de traje y con pesados anteojos cuadrados, a veces oscuros que le daban aire siniestro aunque también eran la moda en aquel entonces. A esta dimensión de la representación, se sumaba la dimensión más opaca o valor permanente, que destacaba el lugar de poder que Geisel detentaba. Era la "gallina- madre" que "cuida" a sus "pollos", era quien espiaba y último se reía, era quien elegía al sucesor presidencial y resolvía la interna militar.

La referencia en O Pasquim a la firmeza y convicción de quien se sabe líder, quedó representada a través de la metáfora del pastor. La designación del sucesor de Geisel y la toma del poder por parte de Figueiredo coincidió con la elección de Juan Pablo I como un nuevo Papa de la Iglesia católica. Su fallecimiento 33 días después y el nombramiento de Juan Pablo II como su sucesor hicieron que el tema vaticano perdurada en la agenda política nacional e internacional. O Pasquim le dedicó varias tapas, notas y chistes a esta coyuntura particular de la cúpula eclesiástica, la cual también inspiró la alegoría del poder pastoral para aludir a Geisel, quien fue representado como un viejo pastor (Figura 3).
Figura 2- Hélio

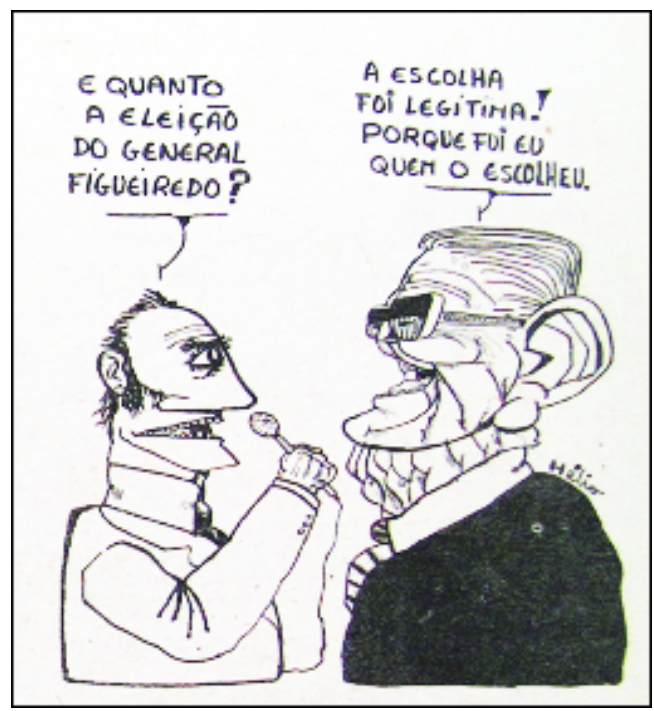

Fonte: O Pasquim n 487, octubre/noviembre 1978

Figura 3- Hélio

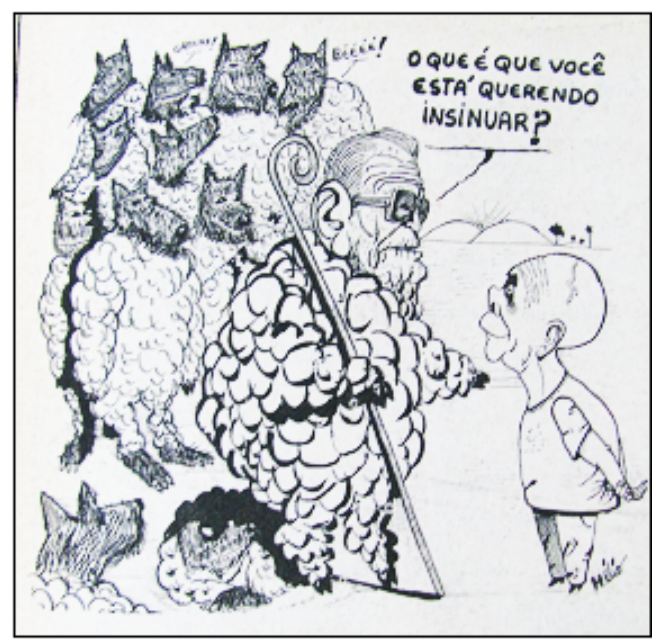

Fonte: O Pasquim n 485 , octubre 1978

El efecto satírico de la metáfora consistía en que el pastor estaba disfrazado de oveja y se lo veía arriar lobos que también se hacían pasar por corderos. Se reconocía de este modo el lugary el poder que Geisel detentaba dentro de la institución de las Fuerzas Armadas y del gobierno. El desenmascaramiento de los "lobos" aludía tanto a las promesas incumplidas sobre la liberalización del 
régimen por parte de Geisel, a la vigencia de la represión, la tortura y la censura; como al poder sin precedentes dentro del Ejército que Geisel había conquistado. Geisel había logrado dominar al sector duro de las Fuerzas Armadas, como señala Skidmore (2004, p. 388), "Geisel demostrara ter acumulado mais poder pessoal do que qualquer dos seus antecesores, sendo prova de isso a decisão sem precedente de demitir o ministro do Exército [geral Sylvio Frota] sem consultar o Alto Comando".

\section{Figueiredo, el locuaz}

La metáfora del pastor anteriormente utilizada por Hélio para referirse a Geisel fue retomada por Nani y varios otros humoristas para representar a Figueiredo. Si bien la apelación al mismo recurso iconográfico permitía establecer una continuidad entre una y otra gestión militar; las versiones que aludían a Figueiredo mostraban sus diferencias. El título de esta serie de charges era "Seis anos de pastor" y se complementaba con la frase del ratón Sig, la mascota de $O$ Pasquim creada por Jaguar, que agregaba: "é nós de ovelhas". Ya no se trataba de un rebaño de lobos disfrazados de ovejas sino que las ovejas representaban al hombre común, a los civiles de las clases subalternas?

7 La representación de lobos y ovejas no era nueva en $O$ Pasquim, en noviembre de 1970, cuando gran parte de su equipo de redacción fue metido en presión, publicó en tapa una ilustración en la cual un lobo le decía una oveja asustada, que intentaba esconderse tras un nos arbustos: "Enfim um Pasquim inteiramente automático: sem o Zirando, sem o Jaguar, sem o Tarso, sem o Francis, sem o Millôr, sem o Flávio, sem o Sérgio, sem o Fortuna, sem o Garcez, sem a redação, sem a contabilidade, sem a gerência e sem caixa" (OP nº 73, nov. 1970).
Pero éstas habían entrado en la lógica militar así que marchaban en filas como soldados subalternos según la jerarquía castrense, al grito de "Figueiredo, Figueiredo, Figueiredo, Figueiredo", remitiendo a las movilizaciones fascistas. Al pie de la imagen, un texto parafraseaba una célebre frase de Figueiredo: "o cheiro de carneiro é melhor que o cheiro do povo" (OP n ${ }^{\circ} 486$, oct. 1978. Figura 4). 
Figura 4- Jaguar, Nani, Agner y Duayer

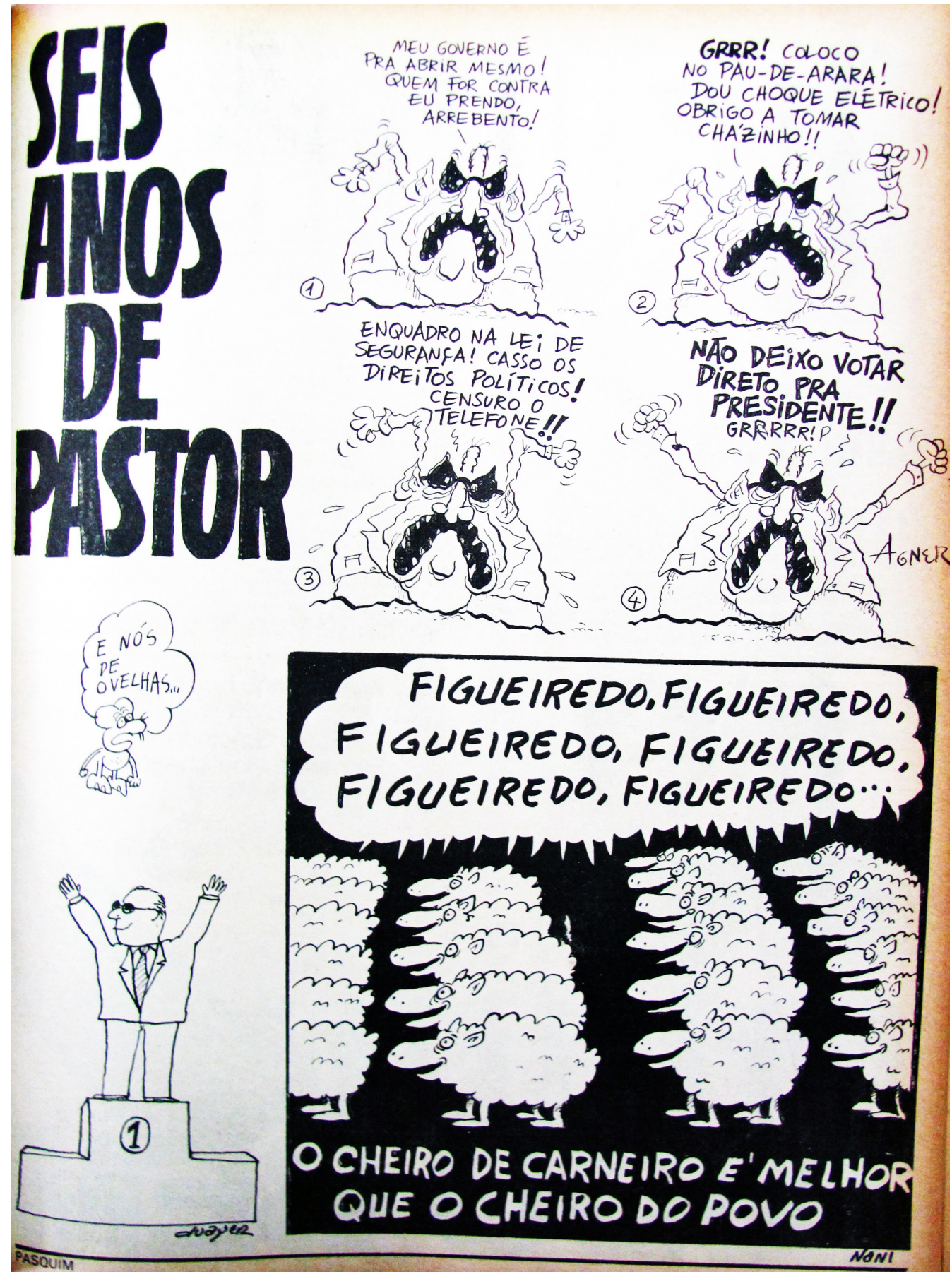

Fonte: O Pasquim n 486 , octubre de 1978

João Figueiredo se caracterizó por su verborragia y por no medir las consecuencias de sus palabras. Según se recuerda en una nota publicada en Folha de São Paulo, tras la designación de Figueiredo, por entonces a cargo del Serviço Nacional de Informações 
(SNI), el gobierno inició una campaña para popularizar su imagen llamándolo "João do Povo"8 (02/11/2000). La iniciativa fracasó debido, en parte, a la personalidad del futuro presidente. En agosto de 1978, en una entrevista al referirse Figueiredo a su afición por los caballos, el periodista le preguntó si le gustaba el "olor a pueblo" y aquel respondió: "O cheirinho do cavalo é melhor (do que o do povo)". La frase dejaba en evidencia con qué espíritu estaba dispuesto a cumplir con el objetivo de avanzar en la lenta y gradual transición democrática que él mismo había anunciado. La frase como el caballo inspiró múltiples chistes a lo largo de su presidencia. Por ejemplo, en un cartoon de Agner, Figueiredo aspirara "odor de cavalo" con una máscara antes de tener contacto con el "pueblo" (OP n 479, sep. 1978. Ver: Figura 5). La reiterada alusión a esta frase contribuyó a ejercitar la memoria, a recordarles a los lectores el desprecio que el mandatario tenía por el pueblo y por la ciudadanía a la cual consideraba sus subordinados.

Figura 5- Agner

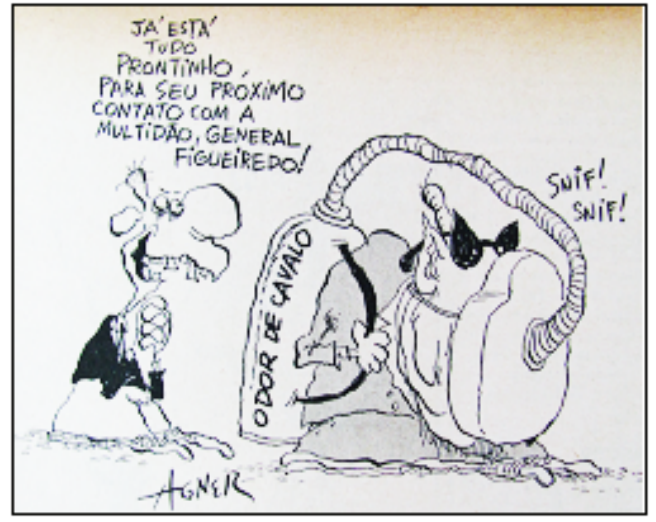

Fonte: O Pasquim n 479, septiembre de 1978
Figura 6- Marcon

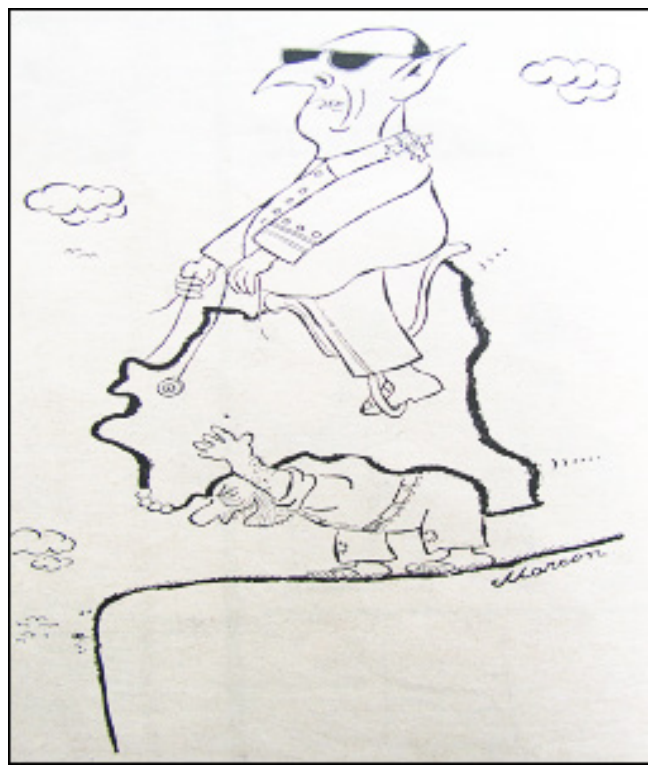

Fonte: O Pasquim n 507, abril 1979

La figura del caballo suele ser un emblema de heroicidad y triunfalismo en la iconografía política de Occidente. Desde el Renacimiento, las estatuas ecuestres, recuperando la tradición clásica, "hacen visible y palpable la metáfora del gobierno como ejercicio de equitación" (BURKE, 2005, p. 85). Durante las monarquías absolutas, esta representación, señala Burke (2005), contribuyó a reforzar la idea de que el rey estaba por encima de la ley. Fue tras la Revolución Francesa y las proclamas de libertad, igualdad y fraternidad que las convenciones retratísticas se modificaron a favor, primero, del gobernante burócrata y luego, del gobernante jovial, viril y de condición atlética. No obstante estas transformaciones de la iconografía política, el simbolismo de gobernantes a caballo se mantiene activo en la memoria visual y en la cultura popular y masiva, siendo un recurso recurrente para la caricatura.

Las caricaturas de Figueiredo a caballo eran una parodia de su poder, del modo en que ejercerlo y de legitimarlo. Marcon lo

8 Ver: Veja no 513, 05/07/1978. 
cuestionó al mostrar un Figueiredo altivo montado a un Brasil que se dirigía hacia un precipicio en andas de un pobre trabajador $\left(O P n^{\circ}\right.$ 507, abr. 1979. Figura 6). En otro caso, Figueiredo intentaba controlar a un caballo desbocado que representaba la "Inflação galopante" que también lo conducía a un precipicio (OP n ${ }^{\circ}$ 500, ene.-feb. 1979). O se lo veía a la carrera, hasta toparse abruptamente con unos huelguistas que le impedían el paso (OP n 508, mar. 1979).

Sin embargo, Figueiredo demostró más capacidad para gobernar y sostener la dictadura de la que la oposición y los humoristas hubiesen deseado. Los cambios en las representaciones de Figueiredo en $\mathrm{O}$ Pasquim registran este hecho. A mediados de 1979, se lo ve haciendo equitación, montado a la urna del Tribunal Superior Electoral (TSE) a modo de caballo, saltando ágilmente los "obstáculos": el MDB (OP, n 521, jun. 1979). Si al principio Figueiredo estaba "al borde del abismo", a un año de su gobierno la revista admitía que le ganaba 1 a 0 a Brasil. Un Figueiredo, tranquilo y triunfal se alejaba en su caballo después de que éste dejara en primer plano la "torta" de cumpleaños (OP $n^{\circ}$ 559, mar. 1980. Figura 7). En la misma sintonía, un relajado y contento Figueiredo paseaba en un carro tirado por un hombre el cual, como si fuese el caballo, llevaba unas anteojeras que le impedían distraerse del cartel que a modo de zanahoria lo incentivaba a avanzar sin protestar: "Juro fazer deste país uma democracia". A un costado del camino, un mojón anunciaba el comienzo del " ${ }^{\circ}$ ano" de gobierno de Figueiredo (Figura 8). Se recuperaba aquí la idea de la manipulación de la ciudadanía antes expuesta a partir de la metáfora del rebaño y el pastor.
Figura 7- Marcon

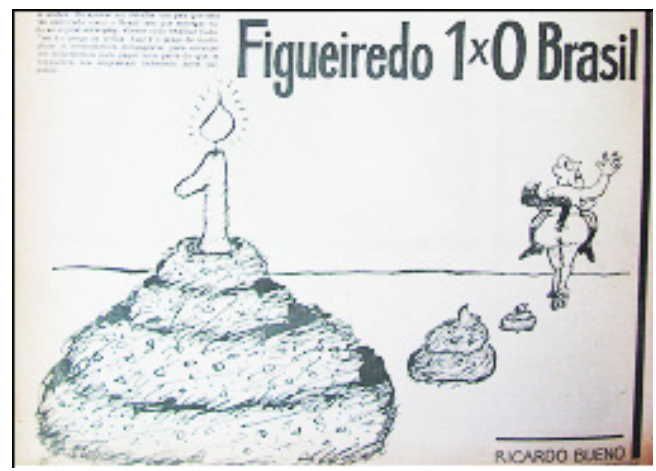

Fonte: O Pasquim, nº 559, mar. 1980

Figura 8- Mariano

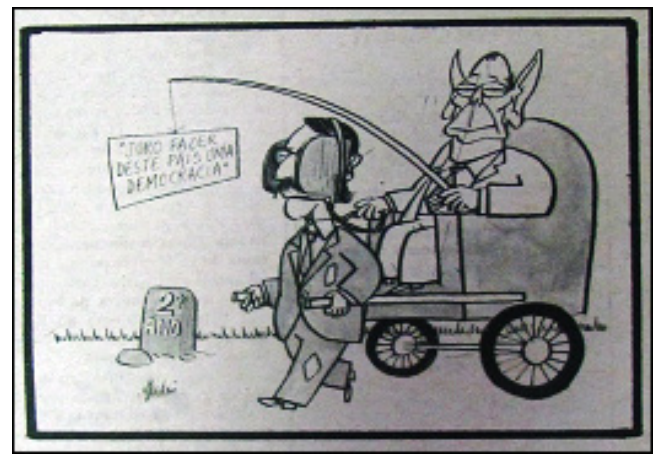

Fonte: O Pasquim, n 559, mar. 1980

La imagen del gobernante jovial, viril y de condición atlética que Figueiredo también quiso dar también motivó caricaturas diversas en O Pasquim. La noticia de que el presidente había bajado de peso haciendo actividad física motivó los chistes más diversos y fue, sobretodo, la excusa para expresar la crítica en torno a la fuerte desigualdad social, la difícil situación económica, la vigencia de la represión y del régimen dictatorial, entre otros. Henfil en su sección "Primo Figueiredo", que consistía en cartas en las cuales interpelaba al presidente como su fuese un pariente, explicaba:

Você está muito bonito na foto oficial de Presidente da República que foi mandada imprimir em 40 mil cópias para que, fixadas nas 
paredes públicas, todos possam ver o sorriso de dentes perfectos, a face corada, confiante e alegre do mais saudável Chefe da nação do mundo occidental

Y agregaba "Como podemos retribuir tão grande gentileza? [...] vamos the a oferecer a foto oficial do povo brasileiro (OP $\mathrm{n}^{\circ} 521$, jun. 1979). En efecto, O Pasquim desde sus textos e imágenes ofreció la imagen del pueblo brasileño que no era precisamente la imagen oficial del mismo: hombres y mujeres que perdían peso pero no por hacer ejercicio o régimen sino porque estaban pasando hambre; un pueblo que por protestar era reprimido y torturado; un pueblo que era testigo de cómo unos pocos se "comían" el mejor asado; un pueblo que debía soportar que su presidente prefiera el "régimen" militar -había un juego con el significado de "régimen"-, y su "plato favorito" fuese un tanque militar. Distintas imágenes de Brasil estaban en disputa, las oficiales, por un lado, y, las opositoras, por otro, que buscaban desacreditar a las anteriores. Lucha simbólica desigual, en particular, cuando tienen lugar bajo regímenes dictatoriales que se caracterizan por las restricciones del espacio público.

Sin embargo, bajo el gobierno de Figueiredo no fueron las caricaturas lo que más disgustaba a los censores y a las autoridades más bien, fueron los fotomontajes publicados por O Pasquim. Un caso emblemático involucró al número que conmemoraba el primer año de la gestión de Figueiredo. Las provocativas imágenes de la tapa y contratapa fueron censuradas. Bajo el título "1 ano da abertura de Figueiredo", un fotografía muestra a una mujer gorda de espaldas en el desfile de campeones de las Escolas do Samba. Como bien describe Braga (1991), en la euforia del baile la mujer se había bajado su bikini, mostrando su cola desnuda al fotógrafo. O Pasquim le agregó un globo que decía: "Aquí ó!" en provocativa referencia a la apertura (OP n 559, mar. 1980. Figura 9). La contratapa era peor: se trataba de una fotografía en el cual de una torta gigante de cumpleaños sale una muchacha, la cual es festejada por los hombres de traje que la rodean (Figura 10). En el fotomontaje, las cabezas de esos hombres fueron sustituidas por las caras de los ministros de Figueiredo, quienes emitían frases provocativas como "coisinha fofa", "tira tudo", "um aninho... mas com un corpinho de 16..." (en alusión a la "edad" de la dictadura en aquel entonces). La cabeza de la muchacha que salía de la torta había sido reemplazada por la de Figueiredo.

Figuras 9 y 10- Tapa y contratapa - referencia a la apertura

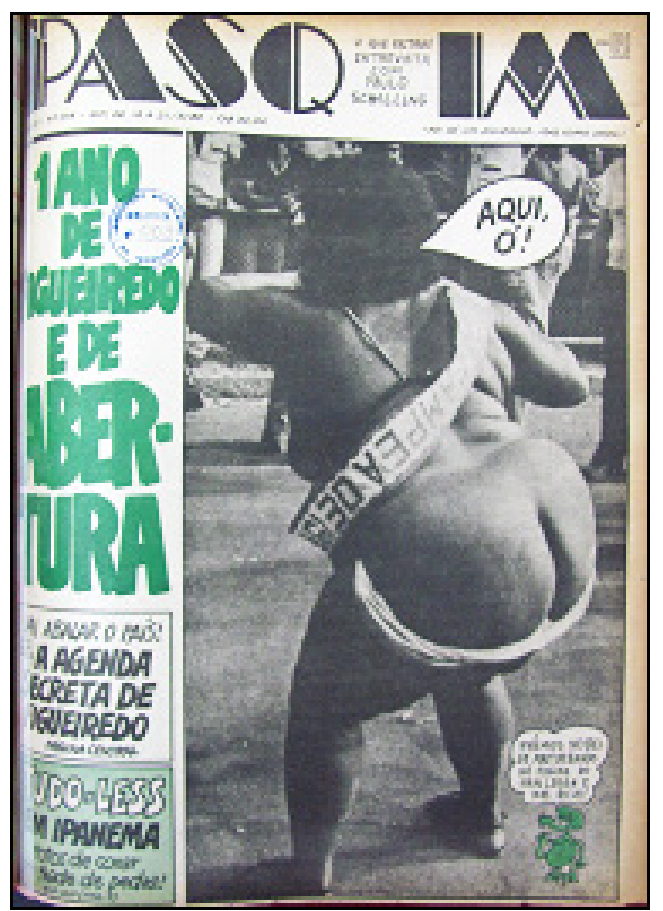




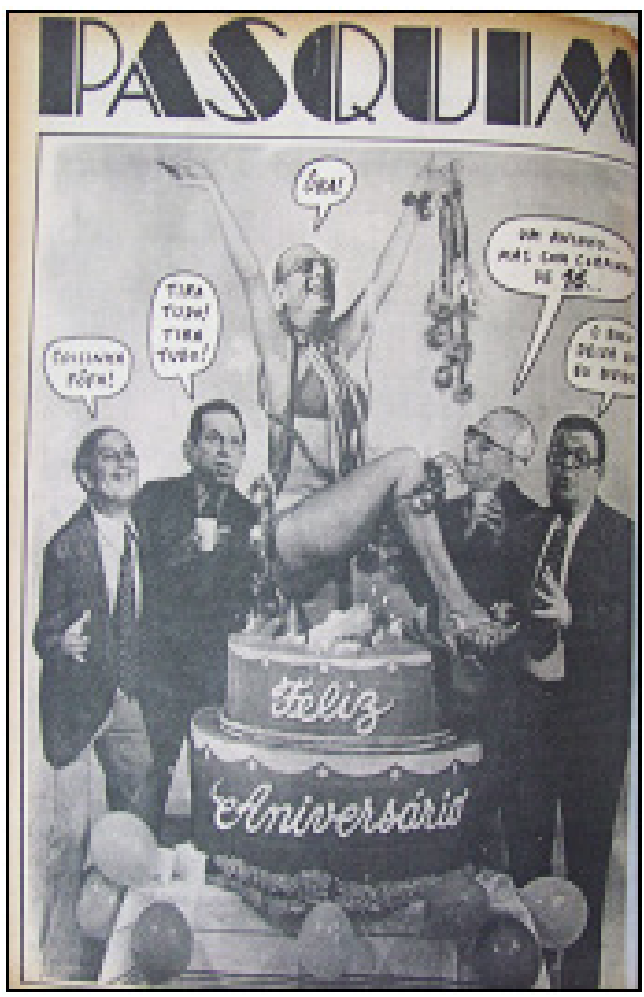

Fonte: O Pasquim nº 559, marzo de 1980

Figura 11- Eles perderam a cabeça

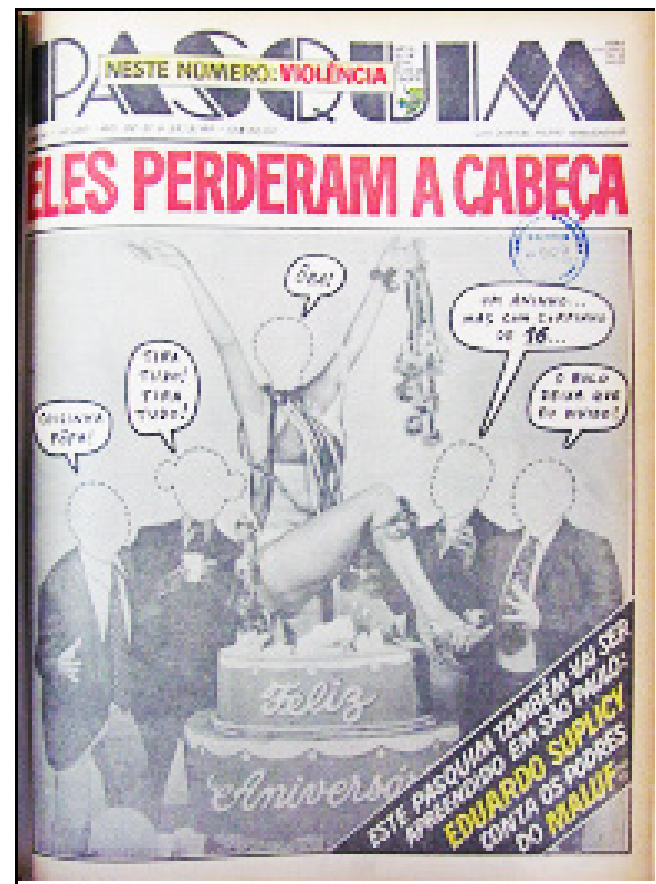

Fonte: O Pasquim nº 560, marzo de 1980
Este número de O Pasquim fue censurado y capturado, impidiéndose su circulación (Cl-DPF, Informe confidencial $n^{\circ} 2360$, 05/1980). Días previos a la orden de aprensión, el ministro de Justicia Ibrahim AbiAckel había recibido una carta de José Vieira Madeira, director de la Divisão de Censura de Diversões Públicas, en la cual sugería aplicar la Ley de Prensa n 5250/67 sobre el semanario no sólo para impedir la circulación del número en cuestión sino para suspenderla por reincidencia en la infracción según lo establecido en el artículo $n^{\circ}$ 62. Madeira justificaba la censura argumentando que los contenidos de O Pasquim eran una ofensa sistemática a la moral pública y a las buenas costumbres de Brasil (Ofício n ${ }^{\circ}$ 012/80SO/DCDP, 18/03/1980). El pedido fue en parte desoído, la revista no fue suspendida completamente sino que se secuestró el número en cuestión.

Este hecho no amedrentó a los editores de $O$ Pasquim, que en el número siguiente aludieron al secuestro, intentando sacar provechoy desafiando aún más a la censura. En la portada publicaron la misma fotografía que en la contratapa del número anterior pero sin los retratos de los ministros ni del presidente, tan solo unas líneas punteadas contorneaban las cabezas. El título era "Eles perderam a cabeça" (OP n 560, mar. 1980. Figura 11). O Pasquim había logrado enloquecer a las más altas autoridades nacionales. En la frase de este número se definían como “Um jornal muito apreensivo" y auguraban que ese número podría volver a ser censurado, en particular, en São Paulo donde se habían secuestrado la mayor cantidad de ejemplares del $n^{\circ}$ 559, aproximadamente 15.000 (Cl-DPF, Informe confidencial $n^{\circ} 2360$, 05/1980). Como en anteriores ocasiones, a pesar de la censura y las amenazas, la revista logró sobrevivir. 
Como se mencionó anteriormente, la locuacidad de Figueiredo fue materia prima privilegiada de los humoristas. Dos casos se destacan en los cuales sus dichos fueron motivo de burlas diversas, uno ocurrió antes de que asumiera el cargo de presidente, cuando en medio de su "cruzada populista", según la definición que Veja hizo de su campaña (n 513, 05/07/1978), prometió "prender quem não quiser a abertura"; y el segundo caso, fue en 1983, cuando en medio del masivo reclamo por elecciones directas para presidente, se pronunció a favor y después tuvo que desmentirse.

En el primer caso, los humoristas expresaron su incredulidad en cuanto a que efectivamente Figueiredo fuese capaz de detener a quienes se opusieran a la apertura democrática; principalmente, porque, como sugería Reinaldo, tendría que apresarse a sí mismo. Figueiredo quedaba en ridículo al intentar desdoblarse en quien debía ser detenido y en quien hacía la detención (OP n ${ }^{\circ}$ 486, oct. 1978). Como en otros casos, este tipo de dislates generaba tensiones dentro de las Fuerzas Armadas y los civiles a éstas aliados. Los humoristas satirizaron las internas militares, intentando sacar provecho de ellas y ampliando los alcances de su sátira. Un cartoon mostraba a Paulo Maluf, preocupado y reconociendo su error: "Xi! Esquecemos da dar corda!"; otro de sus socios políticos decía: "Deu curto-circuito!"; en cambio, para Geisel, simplemente: "Tamos fritos" (OP n 487, oct- nov. 1978).

El segundo caso ocurre en el marco de un clima de fuerte movilización social generado por el movimiento Diretas, já! que reclamaba elecciones directas para presidente. En ese contexto, Figueiredo declaró: "Sou pelas Diretas". Inmediatamente, la prensa dio la noticia y O Pasquim anunció en su portada: "Inédito. O Pasquim apóia o governo federal" y, una caricatura muestra a un suplicante Figueiredo, con lágrimas en los ojos, rogarle al ratón Sig: "Por favor, não me apóie! Não me comprometa!" (OP n 751, nov. 1983. Figura 12). El impacto del título, aunque irónico, era más fuerte que el de la imagen, en este caso, realizada por Jaguar. En el siguiente número, tras la desmentida del mandatario, la tapa de O Pasquim mostraba a un serio y circunspecto Figueiredo decir: "... Não era bem isso..." y, a su lado, Mário Juruna9, cargando su emblemático grabador portátil, comentaba: "homen branco também se atrapalha com língua..." (OP n 752, nov. 1983. Ver: Figura 13). En este caso, la imagen adquiere mayor protagonismo, si bien, el efecto cómico está en el texto. La diferencia estilística entre la caricatura de uno y otro número de $\mathrm{O}$ Pasquim marcaba la diferencia. En el primer caso, el estilo esquemático y redondeado de Jaguar generaba cierta empatía con el personaje caricaturizado; en cambio, el trazo más figurativo y grotesco de Cavalcante y la rigidez dada a ese cuerpo, la ausencia de cuello y los anteojos oscuros, imponían una distancia que eliminaba cualquier tipo de simpatía.

9 Mário Juruna (1942-2002) fue el primer diputado federal brasilero perteneciente a una étnia indígena. En los años setenta se hizo célebre por recorrer los despachos de la Fundação Nacional do Índio, en Brasília, luchando por la delimitación de las tierras para los indígenas, portando siempre un grabador "para registrar tudo o que o branco diz" y constatar que las autoridades, la mayoría de las veces, no cumplían con su palabra. 
Figura 12- Jaguar

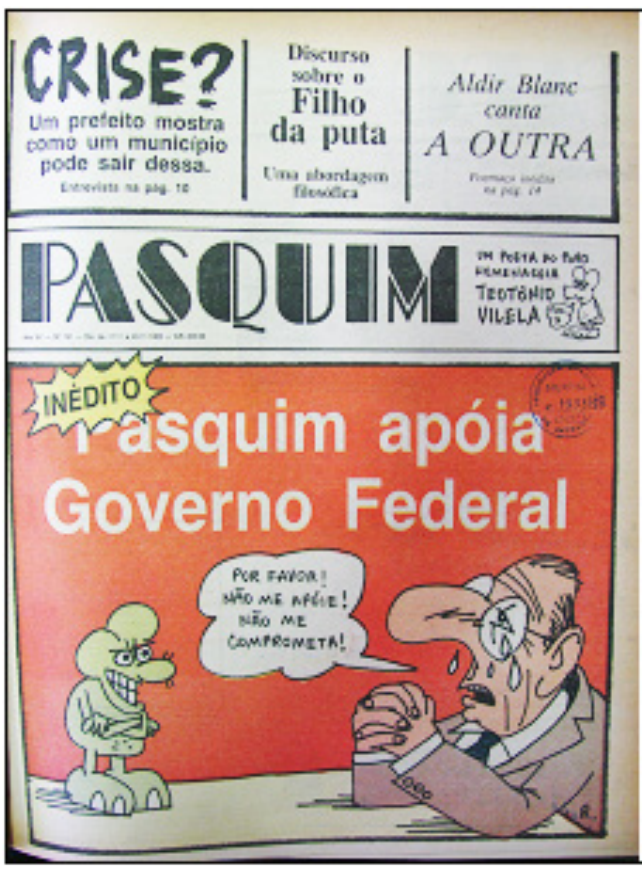

Fonte: O Pasquim n² 751, noviembre de 1983

Figura 13- P. Cavalcant

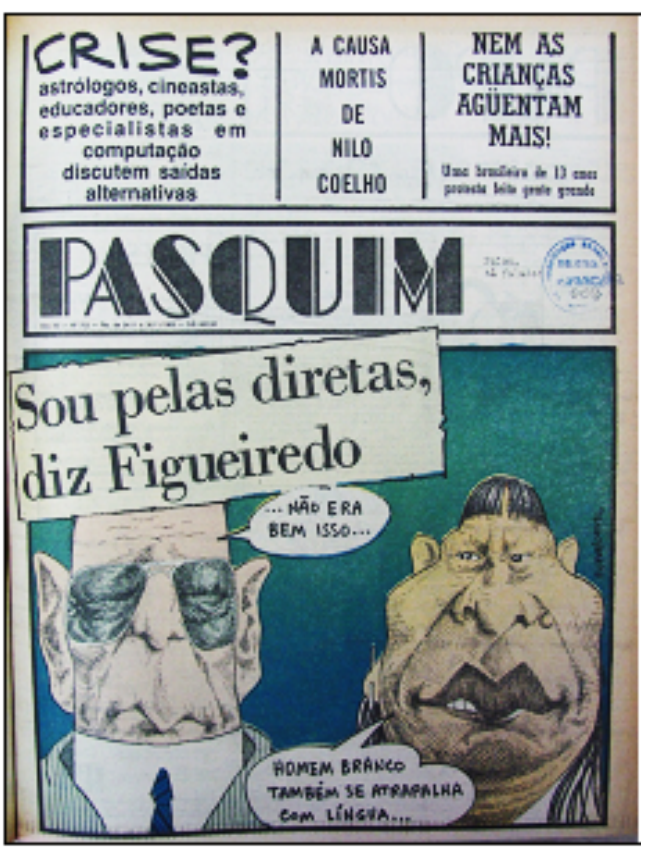

Fonte: O Pasquim $\mathrm{n}^{\circ} 752$, noviembre de 1983

\section{Reflexiones finales}

La caricatura política se incorporó a $O$ Pasquim cuando este semanario tenía ya una trayectoria de más de diez años. Favorecida por una coyuntura de fuerte movilización social en contra del régimen, este tipo de imagen fue ganando espacio en las páginas de la revista, sin embargo, nunca adquirió un papel preponderante. Más bien, O Pasquim parecía sumar este recurso visual como tantas otras publicaciones de aquel entonces. El limitado desarrollo que tuvo este tipo de imágenes en $O$ Pasquim se debe, por un lado, a que éste ya había definido un contrato de lectura que sin contar con este recurso aún resultaba efectivo; por otro lado, a la falta de costumbre por parte de los humoristas a realizar retratos caricaturescos y en debido a ello, al hecho de que la caricatura política haya quedado en gran medida subsumida al humor gráfico como parte del charge.

No obstante, no hay que desconocer la importancia y el poder de las caricaturas en los primeros años de su uso. A través de ellas, los dibujantes aportaron nuevas formas de ver y entender a las autoridades castrenses, distintas a las imágenes oficiales y oficialistas. Las caricaturas buscaron "embrujar" a Geisel como a Figueiredo, quitarles los títulos de autoridad que arbitrariamente y autoritariamente se habían autoasignado. Seguramente algunas lo lograron más que otras, no obstante, hicieron que la censura estuviera pendiente de este semanario que, a través de la risa cómica, atacaba y degradaba la envestidura presidencial en nombre de valores y principios democráticos. En todo caso, fueron un recurso más empleado por las clases subalternas para enfrentar al régimen militar y desafiarlo en las luchas simbólicas, es decir, en las disputas por el sentido del mundo. 
Figueiredo fue objeto de incontables caricaturas y chistes, más que cualquier otro presidente de la dictadura militar brasileña. Muchos humoristas coincidieron en que las orejas y la nariz eran los rasgos físicos que había que exagerar. Sin embargo, hay retratos caricaturescos más benignos y otros más injuriosos. Entre estos últimos, sobresalen los realizados por Agner. Desde 1978, este humorista fue uno de los únicos en recuperar lo monstruoso y darle al presidente un aire sinistro. Las imágenes de Figueiredo creadas por Agner logran transmitir temor y desprecio por el presidente. El Figueiredo de Agner es un personaje desproporcionado, tiene una gran cabeza acompañada de un pequeño cuerpo encorvado que le hace de marco. Esa gran cabeza es casi calva, con orejas puntiagudas, lleva puestos unos anteojos negros también puntiagudos en sus extremos, y una enorme boca suele mostrar unos dientes afilados en forma de triángulo, lo cual le da aire de fiera (figuras 4 y 5). Si bien, O Pasquim publicó con regularidad los charges de Agner, su representación de Figueiredo no llegó a ser tapa y tampoco fue censurada de modo particular. En general, las caricaturas de Figueiredo en la portada de O Pasquim fueron más benignas, parecería que éste no estaba dispuesto a incrementar el nivel agresivo de las mismas. En cambio, los fotomontajes, ya una de sus marcas registradas, sí fueron más desafiantes y por lo tanto fueron los blanco de censura.

Más allá de los estilos de cada dibujante y de la variedad de recursos utilizados, es cierto que la censura no le quitó el ojo a $O$ Pasquim. El Serviço Nacional de Informações (SNI), responsable de la censura, elaboraba detallados informes de "apreciação" de cada edición del semanario. Para el SNI, O Pasquim vehiculizaba "propaganda adversa", se caracterizaba por "Atacar a honra e a dignidade do Presidente da República e a de Ministerios de Estado, ridicularizar medidas governatarias e ofender a moral e os bons costumes" (SNI, Agência Central, Apreciação $n^{\circ}$ 0446/34/AC/81, 24/03/1981); y por “denegrir a imagen da Revolução de 31 de Março de 64 e ridicularizar campanhas de promoção do Governo" (SNI, Agência Central, Apreciação n 0454/43/AC/81, 24/03/1981). Cabe señalar, que estas caracterizaciones de O Pasquim, realizadas en 1981, no implicaban necesariamente la censura o secuestro de la edición. Pareciera más bien que se trataban de informes confidenciales que seguramente serían de utilidad si, por algún otro motivo, se tomase la decisión de actuar contra el periódico.

\section{Referências}

ALVES, Maria Helena Moreira. Estado e oposição no Brasil (1964-1984). Rio de Janeiro: Vozes, 1984.

BAUDELAIRE, Charles. De la esencia de la risa y en general de lo cómico en las artes plásticas. In: Lo cómico y la caricatura. Madrid: La Balsa de la Medusa, Visor, 1988.

BERGER, Peter. Risa redentora. La dimensión cómica de la experiencia humana. Barcelona: Kairós, 1999.

BRAGA, José Luiz. O Pasquim e os anos 70. Mais pra epa que pra oba.... Brasília: Ed. UNB, 1991.

BURKART, Mara. La caricatura política bajo la dictadura militar en Brasil y Argentina. Los casos de O Pasquim y HUM ${ }^{\circledR}$. Los trabajos y los días. La Plata, año 4, n. 3, p. 196-215, nov. 2012. 
BURKE, Peter. Visto y no visto. El uso de la imagen como documento histórico. Barcelona: Crítica, 2005.

BURUCÚA, José Emilio; KWIATKOWSKI, Nicolás. Estudio introductoria. In: GROSE, Francis. Principios de la caricatura. Seguidos de un ensayo sobre la pintura cómica. Madrid: Katz, 2012.

BURUCÚA, José Emilio. La imagen y la risa. Los pathosformeln de lo cómico en el grabado europeo de la Modernidad temprana. Mérida: Editorial Periférica, 2007.

BUZALAF, Márcia Neme. A censura no Pasquim (1969-1975): As vozes não silenciadas de uma geração. 2009. Tese (Doutorado) - Faculdade de Ciências e Letras de Assis, Universidade Estadual Paulista, Assis, 2009.

CHARTIER, Roger. El mundo como representación. Barcelona: Gedisa, 2005.

DAGNEZE, Cinara Sabadin. O riso em tempos de ditatura: os (não) silenciamentos (re) velados pelo Pasquim no período de 1969 a 1971. 2010. Dissertação (Mestrado em Letras) - Universidade de Passo Fundo, Passo Fundo, 2010.

ESCARPIT, Robert. El humor. Buenos Aires: Eudeba, 1972.

FERREIRA, Diógenes Arruda. O humor como resistencia ao controle social autoritário no Brasil pós-1964: Reflexões sobre a impresa alternativa. In: SIMPOSIO INTERNACIONAL PROCESSO CIVILIZADOR, 12, 2009, Recife.

FIGUEIRERO, Daniel de Oliveira. Humor e resistência: as possibilidades políticas do humor nas charges do jornal O Pasquim. Discursos fotográficos, Londrina, v.9, n.14, p.273-274, jan./jun. 2013.

FREUD, Sigmund. El chiste y su relación con el inconciente. Buenos Aires: Amorrortu Editores, 1986. (Obras Completas).

FREUD, Sigmundo. El humor. Buenos Aires: Amorrortu editores, 1988. (Obras Completas).

GOMBRICH, Ernst. El experimento de la caricatura. In: Arte e ilusión. Estudio sobre la psicología de la representación pictórica. Barcelona: Gustavo Gilli, 1979.

HOBSBAWN, Eric. Historia del siglo XX. Buenos Aires: Crítica, Buenos Aires, 1998.

KUCINSKI, Bernardo. Jornalistas e revolucionários nos tempos da imprensa alternativa. São Paulo: EDUSP, 2003.

MALOSETTI COSTA, Laura. Don Quijote en Buenos Aires. Migraciones del humor y la política. In: JORNADAS DE ESTUDIOS E INVESTIGACIONES, 5., 2002, Buenos Aires. Anais... Buenos Aires: Instituto de Teoría e Historia del Arte "Julio E. Payró", Universidad de Buenos Aires, 2002.

MOORE, Barrington. Los orígenes sociales de la dictadura y de la democracia. 3. ed. Barcelona: Ediciones Península, 1991.

OLIVEIRA, Natali Gisele de. Entre o Engajamento e o Desbunde: resistência e deboche no Pasquim (1969-1979). 2007. Dissertação (Mestrado) - Programa de Mestrado em História e Culturas Políticas, Faculdade de Filosofia e Ciências Humanas da 
Universidade Federal de Minas Gerais, Belo Horizonte, 2007.

PETRINI, Paulo. Gêneros discursivos iconográficos de humor no jornal O Pasquim: uma janela para a liberdade de expressão. 2012. Dissertação (Mestrado) - Programa de Mestrado em Comunicação da Universidade Estadual de Londrina, Londrina, 2012.

QUEIROZ, Andréa Cristina de Barros. O Pasquim: embates entre a cultura política autoritária e a contracultura. Cadernos de História, Ouro Preto, v. $\mathrm{n}^{\circ} \mathrm{VI}$, ano 3, $\mathrm{n}^{\circ} 2$, pp.218- 235 dez. 2008.

QUEIROZ, Andréa Cristina de Barros: O Pasquim: um jornal que só diz a verdade quando está sem imaginação (1969-1991). História \& Perspectivas, Universidade Federal de Uberlândia, Uberlândia $n^{\circ} 31$, pp.229252, jul/dez. 2004

ROMANO, Eduardo. Breve examen de la historieta. In: FORD, Aníbal; RIVERA, Jorge; ROMANO, Eduardo. Medios de comunicación y cultura popular. 3. ed. Buenos Aires: Legasa, 1990.

SKIDMORE, Thomas. Brasil: de Castelo a Tancredo, 1964-1985. 8. ed. Rio de Janeiro: Paz e Terra, 2004.

SOHIET, Rachel. Preconceitos nas charges de O Pasquim: mulheres e a luta pelo controle do corpo. ArtCultura. Revista de História, cultura e arte, Uberlândia, v. 9, n. 14, jan.-jun., 2007.

SOIHET, Rachel. Mockery as an anti-feminist weapon: a conservative instrument wielded by libertarians. Estudos Feministas, Florianópolis, v. 13, p.591-612, dez. 2005. 
